\title{
Tube-dwelling nematodes: tube construction and possible ecological effects on sediment-water interfaces
}

\author{
Stefan Nehring ${ }^{1,}{ }^{*}$, Preben Jensen ${ }^{2,}{ }^{*}$, Sievert Lorenzen ${ }^{3}$ \\ ${ }^{1}$ Institut für Meereskunde an der Universität Kiel, Abteilung Meeresbotanik, Düsternbrooker Weg 20, D-2300 Kiel, \\ Federal Republic of Germany \\ ${ }^{2}$ Sonderforschungsbereich 313 der Universität Kiel, Olshausenstraße 40-60, D-2300 Kiel, Federal Republic of Germany \\ ${ }^{3}$ Zoologisches Institut der Universität Kiel, Olshausenstraße 40-60, D-2300 Kiel, Federal Republic of Germany
}

\begin{abstract}
Free-living marine nematodes of the genus Ptycholaimellus build membranous tubes from detritus bound by released mucus. The mucus is produced by a ventral gland cell opening close to the lips and probably also from hypodermal gland cells along the body wall. The tubes are about $50 \mu \mathrm{m}$ in diameter, sinuous, and situated vertically down to $1 \mathrm{~cm}$ depth; they open at the sediment-water interface. These findings suggest that the nematodes may play a significant role at the interfaces by increasing pore water exchange and stabilizing newly sedimented detritus with excreted mucus.
\end{abstract}

\section{INTRODUCTION}

Nematodes are the most abundant group among benthic metazoans (Remane 1933, Platt \& Warwick 1980). In spite of a large amount of literature on the taxonomy and ecology of nematodes, their mode of existence between sand grains and mud particles is poorly known. This paper is the first to demonstrate that some nematodes (members of the genus Ptycholaimellus) do not live freely in the interstices, but build tubes from detritus.

It has long been recognized that meiofaunal organisms have a high potential for modifying their sedimentary microenvironments (Petr 1976, Anderson \& Meadows 1978, Platt \& Warwick 1980, Hicks \& Coull 1983. Meadows \& Tufail 1986), and harpacticoid copepods, for instance, include tube-building species (Lorenzen 1969, Chandler \& Fleeger 1984). Yet, while estuarine muddy sediments may contain up to 400 ind. $\mathrm{cm}^{-2}$ of nematodes belonging to the genus Ptycholaimellus (Warwick \& Price 1979), tube-living harpacticoid copepods occur in densities of less than 40

\footnotetext{
- Addressee for reprint requests

- Present address: Marine Biological Laboratory, University of Copenhagen, Strandpromenaden 5, DK-3000 Helsingor, Denmark
}

ind. $\mathrm{cm}^{-2}$ (Chandler \& Fleeger 1984). The discovery of tube-dwelling nematodes is thus a significant contribution to the understanding of the microenvironments along horizontal and vertical sediment-water interfaces.

\section{MATERIALS AND METHODS}

Study sites. Since 1986 we have collected sediment samples from the tidal creeks at Westerhever, and from a tidal flat on the island of Sylt, North Sea coast of Germany. In March 1988 we collected detritusenriched coarse sand samples at $5 \mathrm{~m}$ water depth in the vicinity of the islands Hirsholmene, northeastern part of the Kattegat close to Frederikshavn, Denmark. Additional samples were obtained from the Bread and Butter Creek locality in North Inlet, South Carolina, USA (Coull 1985), and from sediments in Dr Tom Chandler's experimental aquaria at the Belle $\mathrm{W}$. Baruch Institute for Marine Biology and Coastal Research, University of South Carolina, USA.

Sample preparation. Qualitative sediment samples were taken with a spoon in Westerhever, on Sylt and in South Carolina, while a dredge was used at Hirsholmene. Living animals were extracted in the laboratory by a combination of shaking and decanting, concentrated on a $45 \mu \mathrm{m}$ mesh size sieve and rinsed into a petri 
dish. This material was used for observing behaviour and for light- and electron microscopy.

Behavioural observations. Ptycholaimellus was picked up from the petri dishes and placed in Boveri dishes with water from the locality; small portions of fine-grained sediment (particle size $<45 \mu \mathrm{m}$ ) were gently dropped into the Boveri dishes with a pipette. Tube-construction was observed through a stereomicroscope and with a Leitz Orthoplan microscope (with water immersion objective) fitted to a videocamera (Sony CCD) which was connected to a videorecorder (Panasonic NV-180). Copies of the recordings were made with a Sony Video Graphic Printer (UP-811).

Ptycholaimellus specimens from Westerhever were also placed into sandwich-aquaria (Thun 1966) with water from the locality after which fine-grained sediment was introduced. The behaviour of the nematodes was followed through a stereo-microscope and an Olympus BHT microscope.

Observations on fixed material. Nematodes were fixed in hot TAF (2 parts triethanolamin, 7 parts $37 \%$ formaldehyde and 91 parts water) and then placed in a droplet of TAF on a microscope slide. This fixation yields the best optical contrast when observed with interference phase contrast microscopy (U. Wyss pers. comm.). Light microscopical observations were made with this technique using a Reichert Polyvar microscope.

Histochemical treatments of nematodes and tubes included fixation in $4 \%$ formaldehyde and dehydration through a graded ethanol series followed by isopropanol and embedding in epoxy resin. Serial sections of $1 \mu \mathrm{m}$ were cut using glass knives and placed serially on drops of water on acid-cleaned slides. The slides were warmed on a hot plate $\left(80^{\circ} \mathrm{C}\right)$ to evaporate the water and to enhance adhesion of the sections to the slide. The periodic acid-Schiff (PAS) reaction was used for localisation of mucopolysaccharides, and alzian blue was applied to show acid mucopolysaccharides which are mainly concentrated in mucoid gland cells. The sections were observed through a Olympus BHT microscope.

For scanning electron microscopy (SEM), nematodes and tubes were extracted from the sediments and fixed in $4 \%$ formaldehyde, washed in distilled water, and dehydrated and critical-point dried (Balzer Union CPD $010)$. The tubes were air dried. Nematodes and tubes were coated with $20 \mathrm{~nm}$ of gold using a Balzer Union SCD 004 sputter, and examined on a Zeiss Nanolab 7 scanning electron microscope.

\section{RESULTS AND DISCUSSION}

In Westerhever and Sylt sediments, we found Ptycholaimellus ponticus (Filipjev, 1922) (ca $1 \mathrm{~mm}$ long and max. 50 um thick) together with detrital agglutinations of varied shapes (Fig. 1A). Some of these agglutinations consisted of membranous tubes (PAS staining positive) up to $50 \mu \mathrm{m}$ in diameter to which mud particles, fragments of diatom frustules adhered (Fig. 1B, C). The inner surface appeared smooth (Fig. 1D). Some tubes appeared more sinuous than others, and branched tubes were sometimes found.

To test whether these tubes are made by Ptycholaimellus ponticus we extracted living specimens and placed them in Boveri dishes with water from the locality. The nematodes fix their tails to the bottom of the dish by a few $\mu$ m thick mucous thread, secreted by the caudal gland cells, and make thrashing movements with their bodies. When fine sediment is available their behaviour changes drastically. The body undulates at a lower frequency and the anterior end shows a 3-dimensional wave movement. Upon close contact the head catches a small amount of detritus which attaches to the body. As long as there is detritus in its surrounding, the worm continues to collect and attach particles to its body. This is the beginning of a tube. Tube construction proceeds anteriorly (Fig. 2) and a tube may reach a length of $4 \mathrm{~mm}$ after $3 \mathrm{~h}$ activity; one specimen managed to build a $35 \mathrm{~mm}$ long tube. We never observed $P$. ponticus attaching detritus to the posterior end of the tube, and the worm is unable to turn around in its tube. When a nematode was forced to leave its tube it soon started to construct a new one, hence a home-finding ability could not be detected, in contrast to the tube-building harpacticoid copepod Stenhelia (Delavalia) palustris (Lorenzen 1969). When not collecting detritus, the nematode was active in the detrital agglutinations. We suggest that during this time the membranous inner surface of the tube was formed. Branched tubes were also sometimes constructed in the Boveri dish. Seen from the surface, this amorphous matrix of particles did not appear to be a tube. Only after sieving and shaking, when the loose detritus particles disintegrated, did the sinuous tube appear, identical to those observed in the field samples. The shape of a tube reflects the sinusoidal track of a nematode moving in a jelly (Gray \& Lissman 1964), suggested to describe an elastica (Calcoen \& Roggen 1973). We also observed tube-building by $P$. pandispiculatus (Hopper, 1961) from Bread and Butter salt marsh locality in South Carolina, where we also found tubes of $P$. hibernus Eskin \& Hopper, 1985. Finally, we observed tube construction by a Ptycholaimellus species from Hirsholmene which is closely related to $P$. ponticus and identical to the species reported from a sublittoral locality in the Øresund, Denmark (Jensen 1987). Thus, tube-construction is widespread in Ptycholaimellus species. 

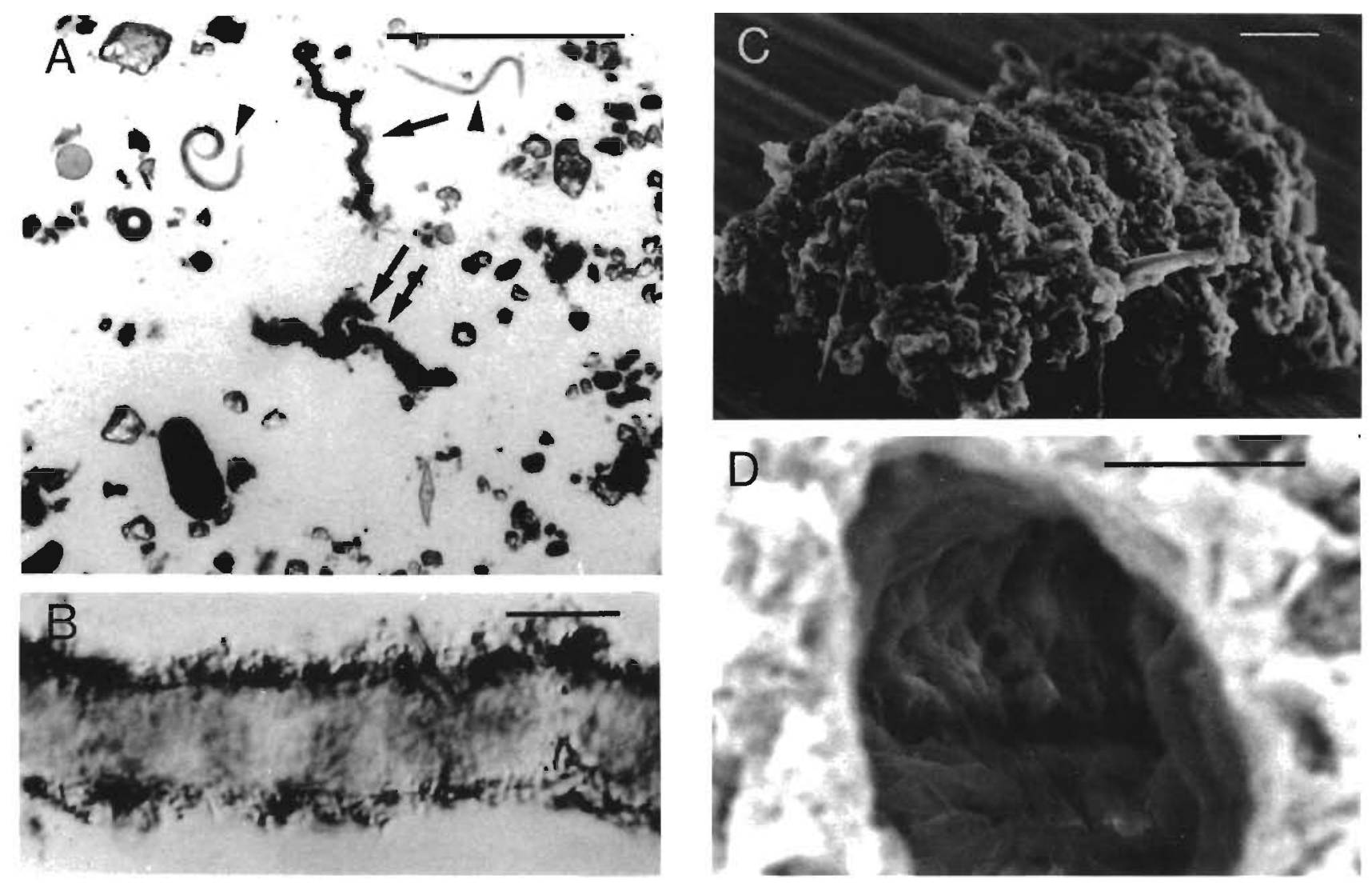

Fig. 1. Ptycholaimellus ponticus. (A) Stereo microscope view of material from a tidal creek in Westerhever, FRG, retained on a $45 \mu \mathrm{m}$ mesh size sieve. Arrowheads: P. ponticus; single arrow: simple tube; double arrows: branched tube; lower left: fecal pellet of mudsnail Hydrobia ulvae; lower right: diatom; scattered sand grains. (B) Phase contrast micrograph of a tube in plane view showing mucoid membrane with smooth inner surface and adhering detritus particles on outer surface. (C) Scanning electron micrograph of a tube made by a young worm. (Tube opening slightly distorted due to alcohol fixation.) (D) View inside the tube with smooth inner surface. Scale bars: (A) $1 \mathrm{~mm}^{\text {(B) }} 50 \mu \mathrm{m}_{\text {; }}$ (C) $20 \mu \mathrm{m}_{\text {i }}$ (D) $10 \mu \mathrm{m}$

The deep sea may harbour nematodes that inhabit tubes (Hope \& Murphy 1969) but if so, the tubes are made by agglutinated foraminifers (Gooday 1984). Riemann (1974) found many irregular tubes of delicate appearence in samples from the Iberian deep sea of which four contained a nematode (Halalaimus). This observation has not since been verified.

We added fine-grained detritus in sandwich aquaria (Thun 1966) containing Ptycholaimellus ponticus. Compact agglutinations of detritus were visible against the looser surrounding material after a few hours. Within each such agglutination there was a tube situated vertically in the sediment which reached the sediment-water interface or extended slightly above the sediment surface (Fig. 2). Moreover, we observed $P$. ponticus gliding forwards and backwards in the tube with the body in close contact to the wall of the tube.

Our observations on tube-construction corroborate those made by Cullen (1973) that nematodes may establish an intricate network of closely spaced burrows in the surface layers of sandy mud. This activity is not necessarily part of the feeding strategy of the nematodes as previously suggested (Riemann \& Schrage 1978, Warwick 1981). Buccal cavity structures of Ptycholaimellus species indicate that they feed on pennate diatoms in a way similar to that of Chromadorita tenuis (G. Schneider, 1906) (Jensen 1982); since we never found these food items on the inner surface of tubes, we conclude that they must feed on diatoms from the sediment surface in the vicinity of the tube opening.

The special activity of the head region in catching detritus (Fig. 2) suggests that a sticky mucus is released there. In Ptycholaimellus spp. the lips are set off from the body by a deep groove (Fig. 3B), into which opens the duct of a large ventral gland cell posterior to the oesophagus (Fig. 3A). Alzian blue and PAS staining revealed that the gland cell and the tubes contain acid mucopolysaccharides, indicating that the ventral gland cell is the site where the sticky mucus is produced. This suggests that it is a very active secretory cell (Narang 1970), although an excretory function has been sug- 

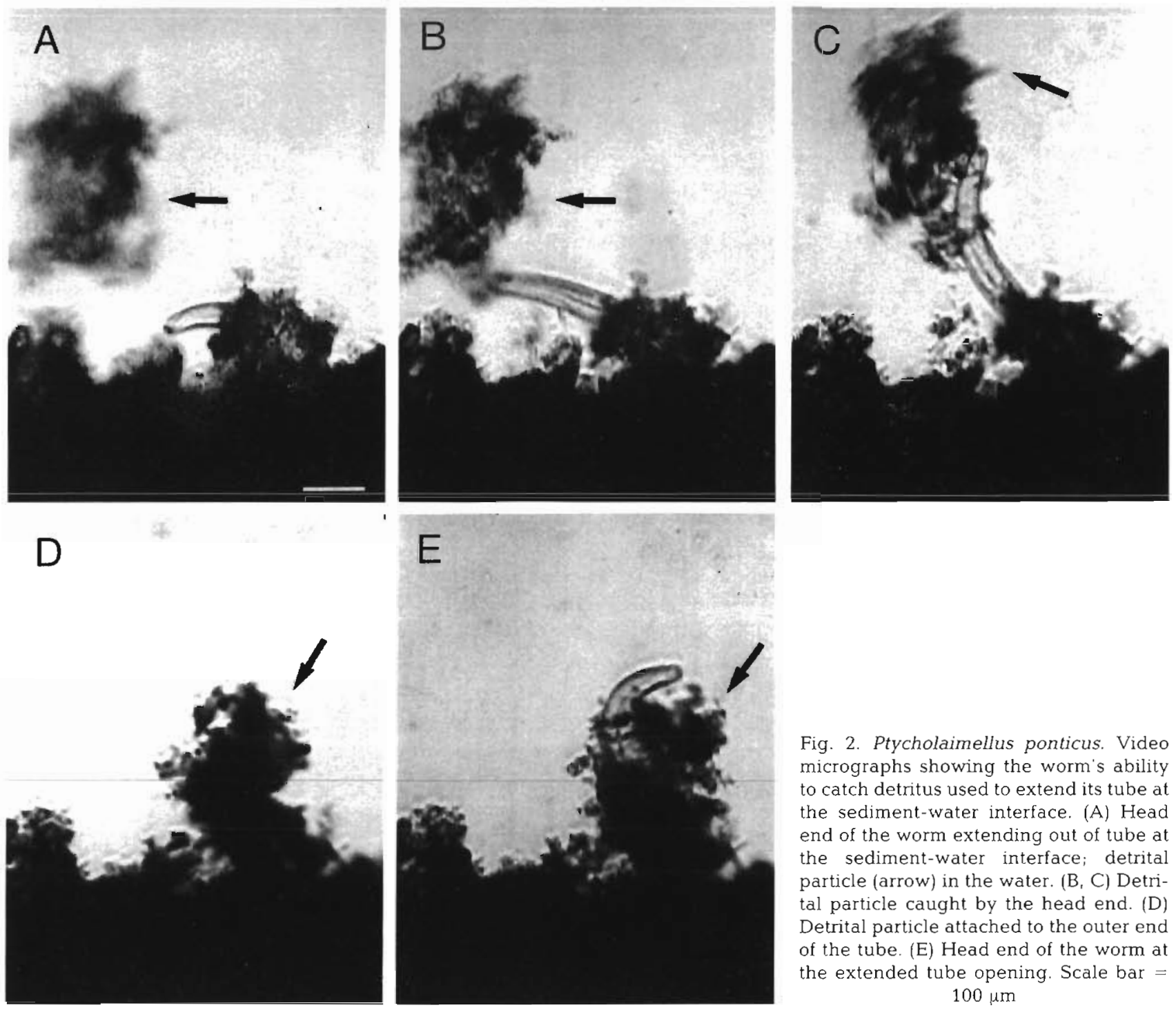

Fig. 2. Ptycholaimellus ponticus. Video micrographs showing the worm's ability to catch detritus used to extend its tube at the sediment-water interface. (A) Head end of the worm extending out of tube at the sediment-water interface; detrital particle (arrow) in the water. $(\mathrm{B}, \mathrm{Cl}$ Detrital particle caught by the head end. (D) Detrital particle attached to the outer end of the tube. (E) Head end of the worm at the extended tube opening. Scale bar $=$ $100 \mu \mathrm{m}$

gested (Maggenti 1981). It is uncertain whether the secretion of the ventral gland cell is also involved in the construction of the membranous tube. Other gland cells opening to the exterior along the body, i.e. hypodermal gland cells (Fig. 3C) (Wright \& Hope 1968, Lippens 1974), could also be the sites of the secretions.

The presence of up to 400 Ptycholaimellus ind. $\mathrm{cm}^{-2}$ (Warwick \& Price 1979) occurring down to about $1 \mathrm{~cm}$ depth (Warwick \& Gee 1984, Eskin \& Palmer 1985, Jensen 1987), and consequently a similar number of tubes, indicates that the total inner-tube surface area could be 5 times higher than the sediment surface. It is probable that the vertical movements of the worms within the tubes result in a substantial vertical transport of water in the upper $\mathrm{cm}$ of the sediment. At the same time the membranous tubes and their binding mucus must stabilize the uppermost layer of newly sedimented detritus and clay and counteract resuspension (Führböter 1983, Meadows \& Tufail 1986). The worms' protected life in the tubes may also explain why they are less well represented in resuspended matter in the water column (Palmer \& Gust 1985) than on the bottom (Eskin \& Palmer 1985).

Acknowledgements. We thank Drs $M$. Elbrächter, H. Rumohr and $U$. Wyss for access to their video equipment and microscopes. Dr E. Haase, Mrs W Rehder and Dr R. Schmaljohann are acknowledged for technical assistance. Dr U. X. Windhövel improved the English. Part of this work was carried out on the Littoral Station List of the Biological Anstalt Helgoland and the Wadden See Station Westerhever of Kiel University, FRG. P. J. appreciates the hospitality at Belle W Baruch Institute for Marine Biology and Coastal Research, University of South Carolina, Columbia, South Carolina, USA. During this study P.J. was visiting scientist at SFB 313 with financial support from the Deutsche Forschungsgemeinschaft. 

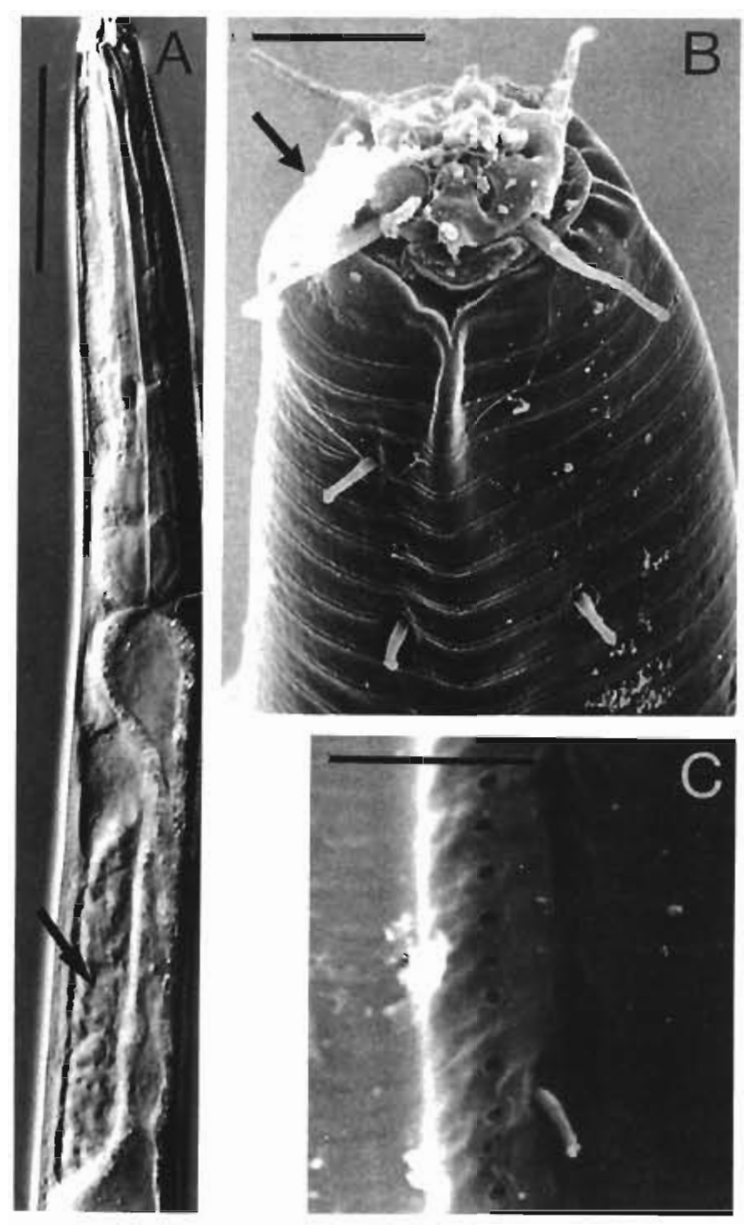

Fig. 3. Ptycholaimellus ponticus. Anterior end in left lateral views. (A) Phase contrast micrograph showing the mucusproducing gland cell (arrow). (B) Scanning electron micrograph showing mucus release (arrow) from a groove between body and lips. (C) Scanning electron micrograph showing row of sublateral cuticular pores. Scale bars: (A) $50 \mu \mathrm{m}$; (B, C) $10 \mu \mathrm{m}$

\section{LITERATURE CITED}

Anderson, J. G., Meadows, P. S. (1978). Microenvironments in marine sediments. Proc. R. Soc. Edinb. 76B: 1-16

Calcoen, J., Roggen, D. R. (1973). The form of moving nematodes. Nematologica 19 (3): 408-410

Chandler, G. T., Fleeger, J. W. (1984). Tube-building by a marine meiobenthic harpacticoid copepod. Mar. Biol. 82: $15-19$

Coull, B. C. (1985). Long-term variability of estuarine meiobenthos: an 11 year study. Mar. Ecol. Prog. Ser. 24: 205-218

Cullen, D. J. (1973). Bioturbation of superficial marine sediments by interstitial meiobenthos. Nature, Lond, 242: 323-324

Eskin, R. A., Palmer, M. A. (1985). Suspension of marine nematodes in a turbulent tidal creek: species patterns. Biol. Bull. mar. biol. Lab., Woods Hole 169: 615-623

Führböter, A. (1983). Über mikrobiologische Einflüsse auf den
Erosionsbeginn bei Sandwatten. Wasser und Boden 3: 106-116

Gooday, A. (1984). Records of deep-sea rhizopod tests inhabited by metazoans in the North-east Atlantic. Sarsia 69: $45-53$

Gray, J., Lissmann, H. W (1964). The locomotion of nematodes. J. exp. Biol. 41: 135-154

Hicks, G. R. F., Coull, B. C. (1983). The ecology of marine meiobenthic harpacticoid copepods. Oceanogr. mar. Biol. A. Rev. 21: $67-175$

Hope, W. D., Murphy, D. G. (1969). Syringonomus typicus new genus, new species (Enoplida: Leptosomatidae) a marine nematode inhabiting arenaceous tubes. Proc. Biol. Soc. Wash. 82: 511-518

Jensen, P. (1982). Diatom-feeding behaviour of the free-living marine nematode Chromadorita tenuis. Nematologica 28 $71-76$

Jensen, P. (1987). Differences in microhabitat, abundance, biomass and body size between oxybiotic and thiobiotic free-living marine nematodes. Oecologia (Berl.) 71: $564-567$

Lippens, P. L. (1974). Ultrastructure of a marine nematode, Chromadorina germanica (Buetschli 1874). II. Cytology of lateral epidermal glands and associated neurocystes. Z Morph. Tiere 79: 283-294

Lorenzen, S. (1969). Harpacticoiden aus dem lenitischen Watt und den Salzwiesen der Nordseeküste. Kieler Meeresforsch. 25: 215-223

Maggenti, A. (1981). General nematology. Springer Verlag, New York

Meadows, P. S., Tufail, A. (1986). Bioturbation, microbial activity and sediment properties in an estuarine ecosys. tem. Proc. R. Soc. Edinb. 90B: 129-142

Narang, H. K. (1970). The excretory system of nematodes: structure and ultrastructure of the excretory system of Enoplus brevis. Nematologica 16: 517-522

Palmer, M. A., Gust, G. (1985). Dispersal of meiofauna in a turbulent tidal creek. J. mar. Res. 43: 179-210

Petr, $T$ (1976). Bioturbation and exchange of chemicals in the mud-water interface. In: Goltermann, H. L. (ed.) Interactions between sediments and freshwater. Junk, The Hague, p. 216-226

Platt, H. M., Warwick, R. M. (1980). The significance of freeliving nematodes of the littoral ecosystem. In: Price, J. M., Irvine, D. E. G., Farnham, W. F. (eds.) The shore environment, Vol. 2. Academic Press, London, p. 729-759

Remane, A. (1933). Verteilung und Organisation der benthonischen Mikrofauna der Kieler Bucht. Wiss. Meeresunters. Abt. Kiel 21: 162-221

Riemann, F. (1974). On hemisessile nematodes with flagelliform tails living in marine soft bottoms and on microtubes found in deep sea sediments. Mikrofauna Meeresboden 40:1-15

Riemann, F., Schrage, M. (1978). The mucus-trap hypothesis on feeding of aquatic nematodes and implications for biodegradation and sediment texture. Oecologia (Berl.) 34 : $75-88$

Thun, W. von (1966). Eine Methode zur Kultivierung der Mikrofauna. Veröff. Inst. Meeresforsch. Bremerhaven Sonderband 2: 277-280

Warwick, R. M. (1981). Survival strategies of meiofauna. In: Jones, N. V., Wolff, W. J. (eds.) Feeding and survival strategies of estuarine organisms. Plenum, New York, p. $39-52$

Warwick, R. M., Gee, J. M. (1984). Community structure of estuarine meiobenthos. Mar. Ecol. Prog. Ser 18: 97-111

Warwick, R. M., Price, R. (1979). Ecological and metabolic 
studies on free-living nematodes from a estuarine mudflat. Estuar. coast. mar. Sci. 9: 257-271

Wright, K. A., Hope, W. D. (1968). Elaborations of the cuticle of

This article was presented by Professor T. Fenchel, Helsingor, Denmark
Acanthonchus duplicatus Wieser, 1959 (Nematoda: Cyatholaimidae) as revealed by light and electron microscopy. Can. J. Zool, 46: 1005-1011

Manuscript first received: September 3, 1989 Revised version accepted: March 29, 1990 